\title{
COMPARISON OF DIFFERENTIAL LEUKOCYTE COUNTS IN FISH OF ECONOMIC AND INDICATOR IMPORTANCE
}

\author{
H. MODRÁ' , Z. SVOBODOVÁ1.2. J. KOLÁŘOVÁ2 \\ ${ }^{1}$ University of Veterinary and Pharmaceutical Sciences, Brno, ${ }^{2}$ Research Institute of Fish Culture \\ and Hydrobiology, University of South Bohemia, Vodňany, Czech Republic
}

Received July 30, 1998

Accepted September 21, 1998

\begin{abstract}
Modrá, H., Z. Svobodová, J. Kolářová: Comparison of Differential Leukocyte Counts in Fish of Economic and Indicator Importance. Acta vet. Brno 1998, 67: 215-226.
\end{abstract}

The aim of this study was to determine the percentage of individual types of leukocytes in fish of economic (carp - Cyprinus carpio L., tench - Tinca tinca L., European catfish - Silurus glanis L., rainbow trout - Oncorhynchus mykiss Walb., and indicator importance (bream - Abramis brama L., perch - Perca fluviatilis L., chub - Leuciscus cephalus L., brown trout - Salmo trutta m. fario L.). In all, we examined 191 fish specimens caught in non-contaminated or insignificantly contaminated localities in good state of health during the vegetation season and not within the season of their reproduction. Leukocytes stained according to Giemsa were classified as: lymphocytes, monocytes, myelocytes, metamyelocytes, neutrophilic granulocytes with band and segmented nuclei, eosinophils and basophils. Blood of all the fish species examined was of lymphocytic character. The mean percentage of individual lymphocytes varied from $84.2 \pm 5.08$ to $99.1 \pm 0.99 \%$. The lowest percentage of lymphocytes was found in the rainbow and brown trout $(84.2 \pm 5.08$ and $87.3 \pm 7.21 \%$, respectively), while the highest values were in the perch $(99.1 \pm 0.99$ and $97.5 \pm 3.19 \%)$. Monocytes were sporadic in all the fish species; with the highest mean value found in the female spawner European catfish $(1.42 \pm 1.74 \%$. The highest percentage of granulocytic series cells was found in rainbow $(15.4 \pm 7.80 \%)$ and brown trout $(11.6 \pm 7.23 \%)$; whereas the lowest values in the perch $(0.8 \pm 1.01$ and $2.4 \pm 3.15 \%)$. As far as the granulocytic series cells are concerned, metamyelocytes were most common with regards to their percentage in all the fish species excepting salmonids. There were prevailing band and segmented neutrophils in the rainbow and brown trout. Granulocytes were mostly represented by neutrophils in all the fish species studied. Eosinophilic granulocytes were found sporadically in the tench $(0.17 \pm 0.59 \%)$ and in 3-year old carp $(0.10 \pm 0.19 \%)$. Basophilic granulocytes were not found in any of the fish species examined. We found practically equal percentage of individual types of leukocytes in the carp, bream and perch of various age categories caught under the same conditions and in the same season of the year. There were no significant differences in the percentage of individual leukocytes in male and female spawners of 3-year-old carp. 3-year-old tench, and 2- to 3-year-old brown trout. Our results contribute to the use and help in introducing the examination of differential leukocyte counts as a biological monitoring method to evaluate surface water contamination.

Differential leukocyte count, lymphocytes, monocytes, granulocytes, species differences, age differences, sex differences

Differential leukocyte counts belong to important characteristics of the health state of fish and in many cases they are also helpful in evaluating the immune system. The differential leukocyte count, like other hematological characteristics, is dependent on the fish species (Rowley et al. 1988), physiological age (Hutton 1967; Kashiwagi et al. 1968; Radzinskaya 1966; Thomas et al. 1969), sex (Colgrove 1966; Pravda et al. 1993), season of the year (Pravda et al. 1985; Yokoyama 1960) and different methods of rearing and nutrition (Smith 1968; Golovina 1995; S vobodová et al. 1998). It is also considerably influenced by the health state of fish (Blaxhall 1972; Golovina 1993; Golovin et Golovina 1995; Rehulka 1996). 
Examination of white blood cells including their differential counts is used to evaluate the effect of drugs and anaestetics on fish. The percentage distribution of individual types of leukocytes were studied by Kourril et al. (1989) in the brood tench after application of $\gamma$-globulines, by Svobodová et al. (1987) in carp following application of the anaesthetic agent Menocain, and by Svobodová et al. (1997) after use of malachite green in carp.

Marked changes in the percentage and absolute numbers of individual types of leukocytes are caused by stress factors (Peters 1986: Pulsford et al. 1994), and in particular various kinds of pollution including low levels of $\mathrm{pH}$ (Dheer et al. 1987; Jeziorska 1993). Not only experimental but also field studies on the effect of pollution on the white blood cell values mention decreased counts of leukocytes, decreased percentage and absolute counts of lymphocytes, and, contrary to this, increased percentage and absolute counts of neutrophils. Such changes were caused both by metals and organic pollutants (Dixon and Dick 1985; Vosyliene 1996; Rougier et al. 1994; Schwaiger etal. 1996; Nath and Banerjee 1996) under experimental conditions.

On the other hand, there are papers which mention opposite effects of some pollutants on blood values of fish, i.e. a rise in absolute and relative counts of lymphocytes (Thakur and Sahai 1993; Kumari and Banerjee 1993; Thakur and Pandey 1990; Gill et al. 1991).

Interesting results were obtained evaluating the white blood cell values after acute and long-term action of standard substances used in the aquatic toxicology to control the toxicity tests $\left(\mathrm{K}_{2} \mathrm{Cr}_{2} \mathrm{O}_{7}, \mathrm{ZnSO}_{4} \cdot 7 \mathrm{H}_{2} \mathrm{O}\right.$, p-nitrophenol). After 48 hours of action of these substances in concentrations of around 48 hour LC50 values in the carp it was found that the relative and absolute counts of lymphocytes were significantly decreasing and the counts of granulocytic series cells were increasing. Contrary to this, after 96 days of action of these substances in concentrations of 48 hour LC50 reduced to one third to one hundredth, no marked changes in the white blood cell values were found as compared to control fish (Svobodová et al. 1993ab). Witeska et al. (1995) and Slominska et al. (1995) found similar effects of lead after acute and chronic administration to the carp. The same results caused by ammonia in the carp were obtained by Wlasow and Dabrowska (1990) a Wlasow et al. (1990).

Fish white blood cell examination plays an important role in biological monitoring of surface water contamination. Results of such examinations are given by Trombickij and Gorbunenko (1993) in the bleak (Albumus albumus L.) from the Dnestr river above and below the city of Bendery; B acker et al. (1994) in the plaice (Pleuronectes americanus) from under the effluent discharge from paper mills compared with a reference locality; Jeney et al. (1996) in the roach from under effluent discharges from paper mills; Khan et al. (1996) in the plaice (Pleuronectes americanus) also from under effluent discharges from paper mills. Dubanský et al. (1995) examined the percentage of individual types of leukocytes in various fish species from several localities of the Skalice river contaminated by polychlorinated biphenyls. They introduced the so called "haematological index of fish stress loading", i.e. the ratio of lymphocyte and granulocyte counts expressed in \%. The common gudgeon (Gobio gobio L.) was found to be an important indicator fish in this case because the hematological index of fish stress loading achieved very low values ( 0 to 5$)$ below the source of contamination.

The physiological values of the differential leukocyte count are necessary to compare and evaluate the changes in fish exposed to stress load. This stress load may be artificial as in model experiments or natural due to various reasons. The differences in the blood values may be objectively evaluated in model experiments employing control fish groups. It is, however, different in biological monitoring when fish are caught in natural localities. It is necessary in these cases to compare the white blood values obtained with similar results originating from the same fish category, season of the year and non-contaminated localities.

It is the biological monitoring method that the so-called indicator fish species are used to assess contamination of rivers and dams. For example, there are following fish species used as indicators in the Czech Republic and Germany for the Elbe river- the bream and perch; 
for the Morava river - the chub and perch; for small mountain and submountain rivers - the brown trout; and for water dams - the bream and perch.

In the paper presented we give a survey of percentage of individual types of leukocytes in fish of economic (carp -Cyprinus carpio L., tench - Tinca tinca L., European catfish - Silurus glanis L., rainbow trout - Oncorhynchus mykiss Walb.), and indicator importance (bream Abramis brama L., perch - Perca.fluviatilis L., chub - Leuciscus cephalus L., brown trout Salmo trutta $\mathrm{m}$. fario L.). Fish specimens were caught in non-contaminated or insignificantly contaminated localities in good state of health during the vegetation season and not within the season of their reproduction.

\section{Materials and Methods}

Table 1 surveys the characteristics. dates of examination and origin of the fish species examined. In all, 191 fish specimens of 8 different species were examined. We examined juvenile and adult fish specimens of both sexes

Table 1

Characteristics and origin of the fish examined

\begin{tabular}{|c|c|c|c|c|c|}
\hline Fish species & $\mathrm{n}$ & $\begin{array}{c}\text { Age } \\
\text { (years) }\end{array}$ & $\begin{array}{l}\text { Body weight } \\
\text { in } g \\
\text { mean } \pm \mathrm{SD}\end{array}$ & $\begin{array}{l}\text { Dates of } \\
\text { catching }\end{array}$ & $\begin{array}{l}\text { Locality of } \\
\text { catching }\end{array}$ \\
\hline $\begin{array}{l}\text { Carp } \\
\text { (Cyprinus carpio L.) }\end{array}$ & 10 & 1 & $80.5 \pm 3.5$ & 03.06 .1996 & pond - Vodňany \\
\hline $\begin{array}{l}\text { Carp } \\
\text { (Cyprinus carpio L.) }\end{array}$ & 10 & 2 & $1023.0 \pm 71.9$ & 03. 06. 1996 & pond - Vodňany \\
\hline $\begin{array}{l}\text { Carp } \\
\text { (Cyprinus carpio L.) }\end{array}$ & 20 & 3 & $1618.0 \pm 392.6$ & 01.11 .1994 & pond - Vodňany \\
\hline $\begin{array}{l}\text { Tench } \\
\text { (Tinca tinca L.) }\end{array}$ & 18 & 3 & $165.4 \pm 30.7$ & 26.06 .1996 & pond - Vodñany \\
\hline $\begin{array}{l}\text { European catfish } \\
\text { (females) } \\
\text { (Silurus glanis L.) }\end{array}$ & 6 & $4-6$ & $8330.0 \pm 3093.0$ & 19.06 .1997 & pond - Vodñany \\
\hline $\begin{array}{l}\text { Rainbow trout } \\
\text { Oncorhynchus mykiss- } \\
\text { (Walbaum) }\end{array}$ & 30 & $1 / 2$ & $37.5 \pm 4.4$ & 20.06 .1996 & trout farm Annín \\
\hline $\begin{array}{l}\text { Bream } \\
\text { (Abramis brama L.) }\end{array}$ & 10 & $2-3$ & $94.9 \pm 3.5$ & 24. 06. 1996 & water dam Rímov \\
\hline $\begin{array}{l}\text { Bream } \\
\text { (Abramis brama } \text { L.) }\end{array}$ & 9 & $4-7$ & $306.0 \pm 78.2$ & 24.06 .1996 & water dam Rímov \\
\hline $\begin{array}{l}\text { Perch } \\
\text { (Perca flu'iatilis L.) }\end{array}$ & 20 & $2-4$ & $56.6 \pm 25.6$ & $\begin{array}{l}27.08 .1996 \\
28.08 .1996\end{array}$ & $\begin{array}{l}\text { the Elbe river- } \\
\text { upstream Pardubice } \\
\text { city and in Lysá } \\
\text { nad Labem city }\end{array}$ \\
\hline $\begin{array}{l}\text { Perch } \\
\text { (Perca fluviatilis } \mathrm{L} . \text {.) }\end{array}$ & 10 & $7-9$ & $378.0 \pm 73.0$ & $\begin{array}{l}27.08 .1996 \\
28.08 .1996\end{array}$ & $\begin{array}{l}\text { the Elbe river- } \\
\text { upstream Pardubice } \\
\text { city and in Lysá } \\
\text { nad Labem city }\end{array}$ \\
\hline \begin{tabular}{|l} 
Chub \\
(Leuciscus cephalus L.)
\end{tabular} & 10 & $2-4$ & $102.6 \pm 40.8$ & 18.07 .1996 & $\begin{array}{l}\text { the Otava river - } \\
\text { Kestřany }\end{array}$ \\
\hline $\begin{array}{l}\text { Chub } \\
\text { (Leuciscus cephalus } \text { L.) }\end{array}$ & 10 & $4-7$ & $452.2 \pm 162.1$ & 21.08 .1997 & $\begin{array}{l}\text { the Morava river - } \\
\text { upstream Uh. Hradišté }\end{array}$ \\
\hline $\begin{array}{l}\text { Brown trout } \\
\text { (Salmo trutta } \mathrm{L} \text {.) }\end{array}$ & 23 & $2-3$ & $151.1 \pm 38.3$ & 03.07 .1997 & $\begin{array}{l}\text { the Tichá Orlice } \\
\text { river - Červená } \\
\text { Voda and Lichkov }\end{array}$ \\
\hline
\end{tabular}


with the exception of the generation European catfish of which only females were examined. They were in good health state. without clinical and pathological changes. Immediately after catching the fish. blood samples were taken by cardiac puncture using a heparinized needle and then blood smears were prepared. Blood smears were dried and then fixed by methanol. They were stained according to Giemsa (Hu mas on 1979) and examined using a $1000 \times$ magnification.

We evaluated 200 leukocytic series cells and classified them on account of their morphology and staining as follow's: lymphocytes. monocytes. myelocytes, metamyelocytes, band neutrophils, segmented neutrophils, eosinophils and basophils. Individual techniques of fish blood examination were employed ( $\mathrm{S} v$ obodová et al. 1991).

We compared differential leukocyte counts of various age categories in the carp, bream and perch. Sex variations in the percentage distribution of individual leukocyte types were evaluated in 3-year old carp from the Dremliny pond ( 9 male and 11 female spawners), 3-year old tench from a pond for experiments ( 7 male and 9 female spawners, 2 juvenile specimens) and 2- to 3-year old brow'n trout from the Tichá Orlice river ( 11 male and 12 female spawners). The influence of age and sex variation was statistically evaluated using the t-test (STAT PLUS 1.01 VÚVeL Brno).

\section{Results}

There are the results of determinations of the percentage distribution of individual types of leukocytes in fish species of economic and main indicator importance in Figs 1 to 13. All

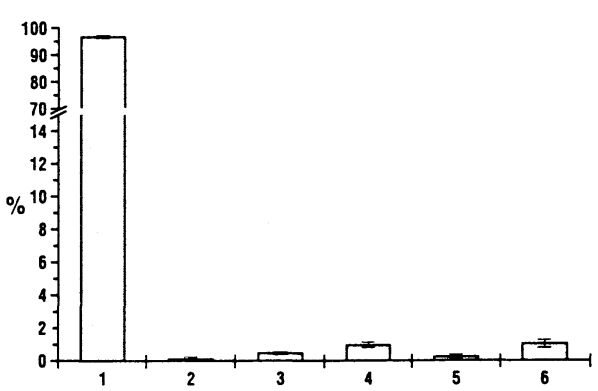

Fig. 1.

Leukocyte differential count in one-year-old carp. Legend: 1 - lymphocytes, 2 - monocytes, 3 myelocytes, 4 - metamyelocytes, 5 - neutrophilic granulocytes, 6 - neutrophilic granulocytes with higher degree of lobation of the nuclei.

the fish species had the blood of lymphocytic character, i.e. lymphocytes prevailed in the white blood cell count. The lowest percentage values of were found in the rainbow and brown trout $(84.20 \pm 5.08 \%$ and $87.30 \pm$ $7.21 \%$, respectively), while the highest values in the perch $(99.10 \pm 0.99 \%$ and $97.50 \pm$ $3.19 \%)$. In all the other fish species examined the mean values of lymphocytes varied from 89 to $97 \%$.

Monocytes represented $1.42 \pm 1.74 \%$ of leukocytes in the brood European catfish and $0.32 \pm 0.74 \%$ in the 3-year old market carp. Approximately $1 \%$ of monocytes out of the total leukocyte count was found in the tench, chub and brown trout. In the rainbow trout and bream of
unted to $0.40 \pm 0.35 \%$ and $0.40 \pm 0.94 \%$, younger age categories the monocytes amounted to $0.40 \pm 0.35 \%$ and $0.40 \pm 0.94 \%$, respectively. Sporadic monocytes were found in 1-year and 2-year-old carp $(0.10 \pm 0.07 \%$

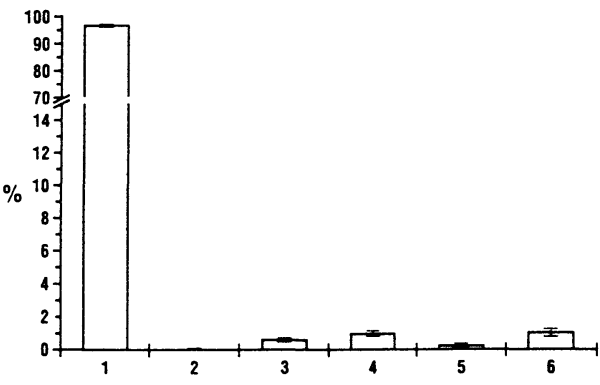

Fig. 2.

Leukocyte differential count in two-year-old carp. For legend see Fig. 1.

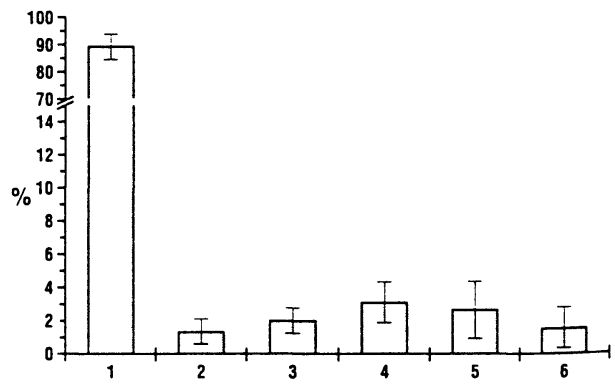

Fig. 3.

Leukocyte differential count in three-year-old carp. For legend see Fig. 1. 


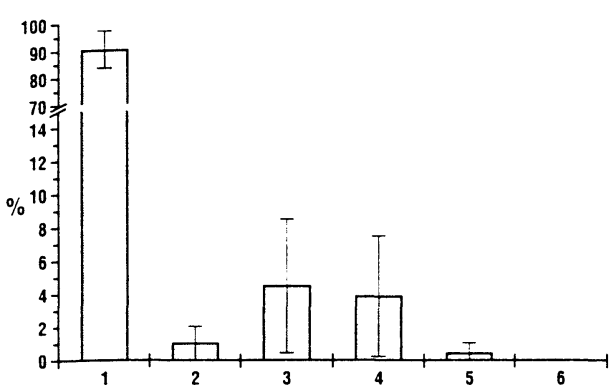

Fig. 4.

Leukocyte differential count in three-year-old tench. For legend see Fig. 1.

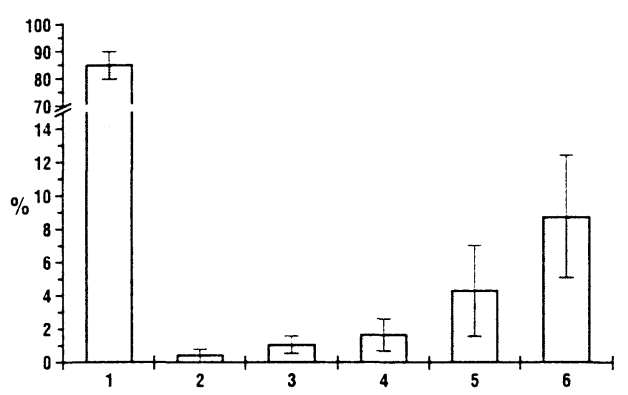

Fig. 6.

Leukocyte differential count in half-year-old rainbow trout. For legend see Fig. 1.

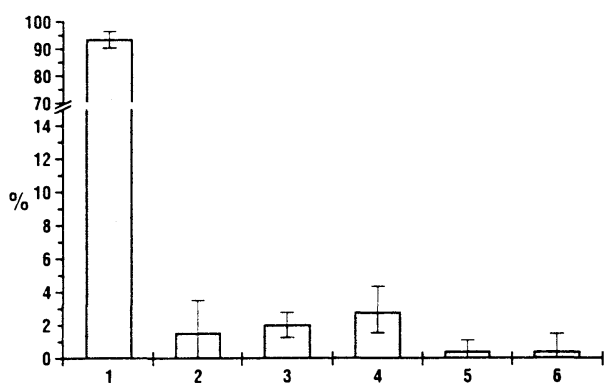

Fig. 5.

Leukocyte differential count in three to six-year-old catfish. For legend see Fig. 1.

and $0.05 \pm 0.05 \%$, respectively), in the older age category of the bream $(0.06 \pm 0.17 \%)$ and in the perch $(0.10 \pm 0.21 \%$ and $0.08 \pm$ $0.24 \%$ ).

As far as granulocytes and their developmental stages are concerned, the percentage values were in inverse relation to the percentage of lymphocytes. It means that the highest percentage of granulocytes was found in rainbow and brown trout $(15.4 \pm$ $7.8 \%$ and $11.6 \pm 7.2 \%$, respectively) and the lowest values in the perch $(0.8 \pm 1.0 \%$ a 2.4 $\pm 3.2 \%$ ). From the granulocytic series cells there were most numerous the

metamyelocytes in all the fish species examined with the exception of salmonids ( 1 -yearold carp $0.95 \pm 0.19 \% ; 2$-year-old carp $1.13 \pm 0.15 \% ; 3$-year-old carp $3.08 \pm 1.23 \%$; 3-yearold tench $3.83 \pm 3.64 \%$; female spawners of the European catfish $5.89 \pm 4.18 \%$; 2 - to 3 -yearold bream $3.75 \pm 2.70 \%$; 4- to 7 -year-old bream $3.44 \pm 1.59 \%$; 2 - to 3-year-old perch 0.88 $\pm 1.52 \%$; 7 - to 9 -year-old perch $0.35 \pm 0.47 \%$ ). Higher percentage of myelocytes was also found in the tench and European catfish $(4.44 \pm 4.03$ a $2.00 \pm 0.76 \%)$. In 1-year and 2-yearold carps we found higher percentage of segmented neutrophils $(1.00 \pm 0.25$ and $1.09 \pm$ $0.27 \%$, respectively), and higher percentage of band neutrophils in 3-year-old carp (2.64 \pm $1.72 \%)$. The band and segmented neutrophils were only sporadic in female spawners of the European catfish $(0.33 \pm 0.55 \%$ and $0.33 \pm 0.74 \%)$. On the other hand, in the rainbow and brown trout band and segmented neutrophils were considerably prevailing (the rainbow trout $4.20 \pm 2.70 \%$ and $8.60 \pm 3.64 \%$; the brown trout $2.74 \pm 1.48 \%$ and $5.84 \pm 3.71 \%$ ). The majority of granulocytes in all the fish species examined were represented by neutrophils. Eosinophils were only sporadically found in the tench $(0.17 \pm 0.59 \%)$ and the 3 -year-old market carp $(0.10 \pm 0.19 \%)$. No basophils were found in any of the fish species examined.

Age differences in the percentage distribution of individual types of leukocytes were evaluated in the carp, bream and perch. In 1 - and 2-year-old carp kept under the same pond conditions and examined during the same season of the year (June 1996) the percentage distribution of individual types of leukocytes was equal (Figures 1 and 2). We compared differential leukocyte counts of two age categories of the bream, i.e. 2- to 3-year-old and 4- 
Table 2

Comparison of the percentage distribution of individual types of leukocytes in female and male spawners of the 3-year-old carp

\begin{tabular}{|l|c|c|}
\hline Leukocytes & $\begin{array}{c}\text { Females } \\
n=11 \\
\text { mean } \pm \mathrm{SD}(\%)\end{array}$ & $\begin{array}{c}\text { Males } \\
\mathrm{n}=9 \\
\text { mean } \pm \mathrm{SD}(\%)\end{array}$ \\
\hline Lymphocytes & $90.38 \pm 4.36$ & $88.19 \pm 4.60$ \\
Monocytes & $1.13 \pm 0.78$ & $1.56 \pm 0.67$ \\
Myelocytes & $1.75 \pm 0.66$ & $2.22 \pm 0.86$ \\
Metamyelocytes & $2.82 \pm 1.40$ & $3.39 \pm 0.99$ \\
Band neutrophils & $2.40 \pm 1.38$ & $2.93 \pm 2.11$ \\
Segmented neutrophils & $1.50 \pm 1.17$ & $1.57 \pm 1.34$ \\
Eosinophils & $0.05 \pm 0.09$ & $0.16 \pm 0.26$ \\
\hline
\end{tabular}

Table 3

Comparison of the percentage distribution of individual types of leukocytes in female and male spawners of the 3-year-old carp

\begin{tabular}{|l|c|c|}
\hline Leukocytes & $\begin{array}{c}\text { Females } \\
\mathrm{n}=11 \\
\text { mean } \pm \mathrm{SD}(\%)\end{array}$ & $\begin{array}{c}\text { Males } \\
\mathrm{n}=9 \\
\text { mean } \pm \mathrm{SD}(\%)\end{array}$ \\
\hline Lymphocytes & $90.38 \pm 4.36$ & $88.19 \pm 4.60$ \\
Monocytes & $1.13 \pm 0.78$ & $1.56 \pm 0.67$ \\
Myelocytes & $1.75 \pm 0.66$ & $2.22 \pm 0.86$ \\
Metamyelocytes & $2.82 \pm 1.40$ & $3.39 \pm 0.99$ \\
Band neutrophils & $2.40 \pm 1.38$ & $2.93 \pm 2.11$ \\
Segmented neutrophils & $1.50 \pm 1.17$ & $1.57 \pm 1.34$ \\
Eosinophils & $0.05 \pm 0.09$ & $0.16 \pm 0.26$ \\
\hline
\end{tabular}

Table 4

Comparison of the percentage distribution of individual types of leukocytes in female and male spawners of the 2- to 3-year-old brown trout

\begin{tabular}{|l|c|c|}
\hline Leukocytes & $\begin{array}{c}\text { Females } \\
\mathrm{n}=12 \\
\text { mean } \pm \mathrm{SD}(\%)\end{array}$ & $\begin{array}{c}\text { Males } \\
\mathrm{n}=11 \\
\text { mean } \pm \mathrm{SD}(\%)\end{array}$ \\
\hline Lymphocytes & $88.38 \pm 6.07$ & $86.09 \pm 8.41$ \\
Monocytes & $0.81 \pm 0.80$ & $1.55 \pm 0.82 *$ \\
Myelocytes & $0.31 \pm 0.46$ & $0.05 \pm 0.15$ \\
Metamyelocytes & $2.18 \pm 2.02$ & $2.64 \pm 3.80$ \\
Band neutrophils & $2.55 \pm 1.11$ & $3.55 \pm 3.45$ \\
Segmented neutrophils & $5.78 \pm 4.06$ & $6.14 \pm 3.32$ \\
\hline
\end{tabular}

to 7-year-old ones. Both groups were caught in the water dam Řimov in the same season of the year (June 1996). The percentage distribution of lymphocytes was practically equal in both the groups $(95.1 \pm 3.4 \%$ and $94.9 \pm 3.5 \%)$. From granulocytic series cells metamyelocytes prevailed in both groups and there were no significant differences in values of their percentage distribution $(3.44 \pm 1.59 \%$ and $3.75 \pm 2.70 \%)$. Likewise, there were 


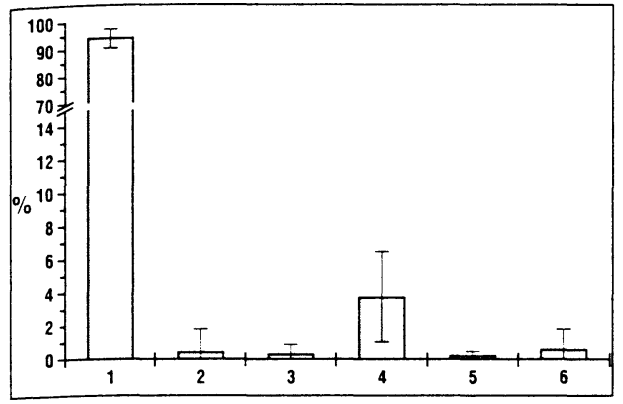

Fig. 7.

Leukocyte differential count in two to three-year-old bream. For legend see Fig. 1.

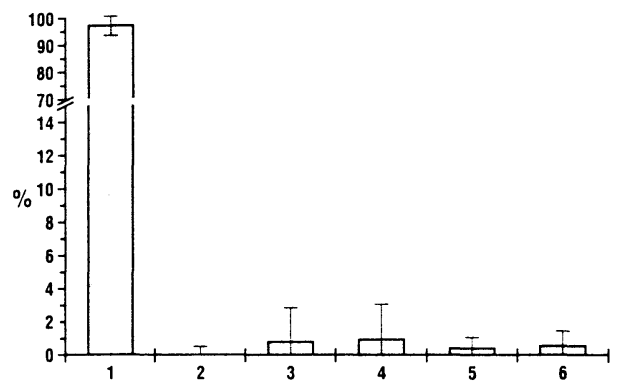

Fig. 9.

Leukocyte differential count in two to four-year-old perch. For legend see Fig. 1.

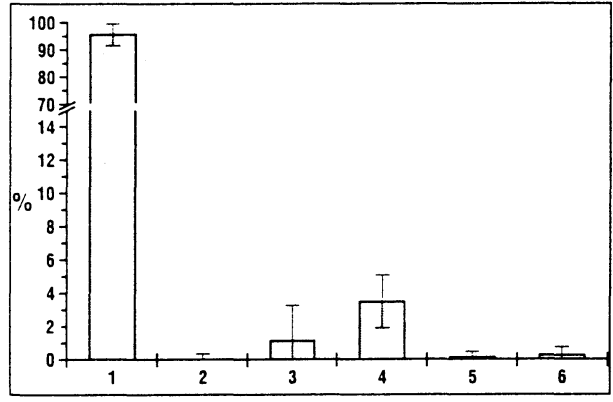

Fig. 8.

Leukocyte differential count in four to seven-year-old bream. For legend see Fig. 1.

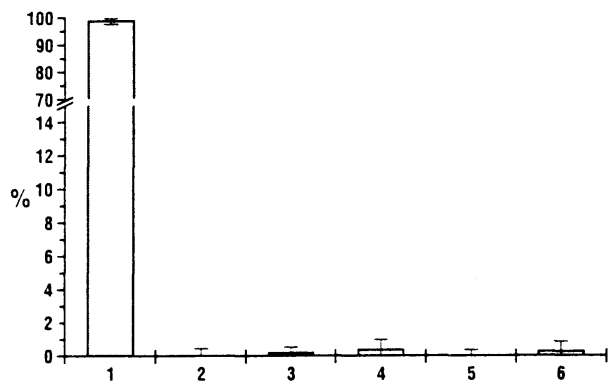

Fig. 10.

Leukocyte differential count in seven to nine-year-old perch. For legend see Fig. 1.

found no significant differences in the percentage distribution of individual types of leukocytes in the two age categories of the perch examined. Both groups of the perch were caught in the Elbe river in the locality upstream Pardubice city and in Lysá nad Labem city in the same season of the year (August 1996). In the younger age category (2- to 4-year-old perch) there were $97.5 \pm 3.2 \%$ of lymphocytes and in the category of older fish (7- to 9-yearold perch) $99.1 \pm 1.0 \%$ of lymphocytes. There prevailed metamyelocytes $(0.88 \pm 1.52 \%$ and $0.35 \pm 0.47 \%$ ) in both groups compared.

Tables 2 to 4 show the percentage distribution of individual types of leukocytes in female and male spawners of the carp, tench and brown trout. There were found no significant differences in values of the percentage distribution of individual types of leukocytes in female and male spawners of the fish species studied. Only male spawners of the brown trout had significantly higher percentage of monocytes as compared with values found in females $(\mathrm{P}<0.05)$.

\section{Discussion}

The prevailing lymphocytic character of the white blood cell series was proven in 8 important economic and indicator fish species and was in accordance with published data (Rowley et al. 1988; Ellis 1977). The highest percentage of lymphocytes was found in 


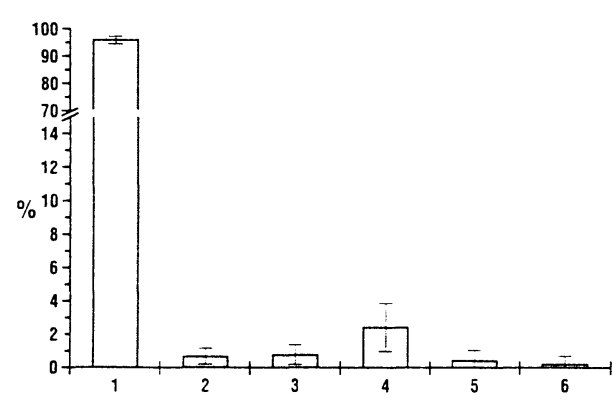

Fig. 11.

Leukocyte differential count in two to three-year-old chub. For legend see Fig. 1.

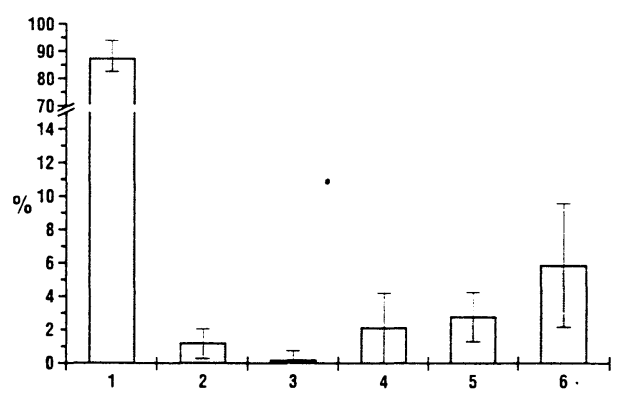

Fig. 13.

Leukocyte differential count in two-year-old brown trout. For legend see Fig. 1. their developmental stages. We cannot, for example, generalize the fact that, unlike in other fish species. there are eosinophils present in the tench and 3-year-old carp. Eosinophils were present in blood samples of only 7 specimens out of 20 examined 3-year-old carp and in 2 specimens from 18 examined 3-year-old tench. Because of these reasons, we do not evaluate and find explanation to the statistical significance $(\mathrm{P}<0.05)$ of the percentage of monocytes in female and male spawners of the brown trout.

In spite of this considerable variability of values of monocytes and granulocytic series cells, some specifics in the fish species examined may be outlined. Monocytes were sporadic in all the fish species (below 1.5\% of the total leukocyte count). The highest percentage of the granulocytic series cells was found in salmonids and the lowest in the perch. Metamyelocytes presented the highest percentage counts in all the fish species examined with the exception of salmonids. Band and segmented neutrophils prevailed in salmonids.

As far as the use of values of the differential leukocyte count is considered, the ratio between the percentage of lymphocytes and granulocytic series cells (myelocytes, metamyelocytes, band and segmented neutrophils, or eosinophils) is crucial. In fish that were subjected to toxic substance influences the ratio becomes narrow (Peters 1986; Wlasow 1985; Svobodová and Pečená 1988; Rougier et al. 1994; Schwaiger et al. 1996; Nath and Banerjee 1996). From our results it is clear that, in using this parameter to evaluate toxic substance influences, it is always necessary to take the fish species into consideration. The ratio of lymphocytes to granulocytes differed significantly 
in individual fish species examined. The lowest ratio number (below 8) was found in salmonids and the highest in the perch (40 to 120). The ratio varied from 10 to 35 in the other fish species.

Greater account of the health or immune state of fish is provided by the number of leukocytes and absolute numbers of individual types of leukocytes compared with values of their percentage distribution. Absolute and relative counts of individual types of leukocytes of control and test fish are compared in model tests. It is, however, not always possible to determine the numbers of leukocytes in cases of surface water contamination because of technical reasons. Therefore, we use the results of percentage distribution of individual types of leukocytes in these cases. In addition to it, there is another problem such as the possibility or impossibility of comparing the results obtained from the examined and reference localities. It happens very often, especially on rivers, that it is not possible to catch the same fish species from upstream and downstream of the source of contamination. Long-term contamination in a river often causes negative changes to fish communities (Vostradovský and Svobodova 1983). From this point of view the significance of this study lies in the area of providing physiological relative distribution of individual types of leukocytes in important fish species. Because of these reasons the analyses of fish were done during the vegetation season and not within the reproductive period. These are the conditions that the monitoring of contamination of rivers and water dams is mostly performed.

Many authors mention changes in the differential leukocyte counts in relation to the species, age, season, reproduction, etc. Our results prove the influence of species, age and sex characteristics. Differences in the relative distribution of individual types of leukocytes were well documented. We did not, however, find age and sex differences in individual fish species examined in the same season of the year and kept under the same conditions in the same localities. We did not compare values of the percentage distribution of leukocytes of 1- and 2-year-old carp caught in June with 3-year-old carp caught in November. We also did not evaluate the age difference in individual fish species originating from different localities (e.g., the chub).

\section{Porovnání poměrného zastoupení jednotlivých typů leukocytů u hospodářsky významných a indikátorových druhů ryb}

Cílem práce bylo stanovit procentuální zastoupení jednotlivých typů leukocytů u hospodářsky významných (kapr obecný - Cyprinus carpio L., lín obecný - Tinca tinca L., sumec velký - Silurus glanis L., pstruh duhový - Oncorhynchus mykiss Walbaum) a u indikátorových druhů ryb (cejn velký - Abramis brama L., okoun říční - Perca fluviatilis L., jelec tloušt - Leuciscus cephalus L., pstruh obecný - Salmo trutta L.). Celkem bylo vyšetřeno 191 kusủ ryb odlovených $\mathrm{z}$ nekontaminovaných nebo z nevýznamně kontaminovaných lokalit. Ryby dobrého zdravotního stavu byly vyšetřovány ve vegetační sezóně. mimo reprodukční období. Leukocyty obarvené dle Giemsy byly řazeny do následujicích kategorií: lymfocyt, monocyt, myelocyt, metamyelocyt, neutrofilní granulocyt s tyčkovitým a se segmentovaným jádrem, eosinofilní a basofilní granulocyt. Krev všech vyšetřovaných druhủ ryb měla lymfocytární charakter. Průměrné hodnoty zastoupení lymfocytů se pohybovaly v rozmezí $84,2 \pm 5,08$ až $99,1 \pm 0,99 \%$. Nejnižší procento lymfocytů bylo zaznamenáno u pstruhů duhových a u pstruhů obecných $(84,2 \pm$ $5,08$ a $87,3 \pm 7,21 \%)$, nejvyšší hodnoty byly zjištěny u okounů říčních $(99,1 \pm 0,99$ 
a $97,5 \pm 3.19 \%$ ). Monocyty byly u všech druhů ryb zastoupeny ojediněle, nejvyšší průměrná hodnota byla zjištěna u jikernaček sumce velkého $1,42 \pm 1,74 \%$. Nejvyšší procento buněk granulocytární řady bylo nalezeno u pstruhú duhových $15,4 \pm 7.80 \%$ a u pstruhů obecných $11,67,23 \%$; nejnižší hodnoty bỵly zjištěny u okounú říčních $(0.8 \pm 1,01$ a $2.4 \pm 3,15 \%)$. Z buněk granulocytární řady měly u všech druhů ryb s výjimkou lososovitých nejvyšší procentické zastoupení metamyelocyty. U pstruhů duhových a u pstruhů obecných převažovaly neutrofilní granulocyty s Iyčkovitým a se segmentovaným jádrem. Převážnou většinu granulocytů $u$ všech sledovaných druhů ryb tvořily neutrofilní granulocyty. Eosinofilní granulocyty byly nalezeny ojediněle u lína $(0.17 \pm 0.59 \%)$ a u 3letého kapra $(0,10 \pm 0,19 \%)$. Bazofilní granulocyty nebyly nalezeny u žádného z vyšetřovaných druhů ryb. U kaprů, cejnů velkých a u okounů říních různých věkových kategorií, odebraných ve stejných podmínkách a vyšetřovaných ve stejném ročním období byly hodnoty procentického zastoupení jednotlivých typů leukocytů prakticky shodné. U mlíčáků a jikernaček 3letých kaprů, 3letých linů a 2-3letých pstruhů obecných nebyly zjištěny signifikantní rozdíly mezi hodnotami procentuálního zastoupení jednotlivých typů leukocytů. Výsledky práce jsou přínosem pro zavedení vyšetřování leukogramů ryb jako jedné z metod biologického monitoringu kontaminace povrchových vod.

\section{Acknowledgements}

This research was supported as Project MR/14/95 Environment Assessment: monitoring of toxic substance occurrence in the food chain by the Ministry of Environment of the Czech Republic and as Project 6051 ..Breeding technologies and health protection of fish and crayfish under intensive and marginal conditions" NAZV of the Ministry of Agriculture of the Czech Republic.We are also grateful to Robin Srnec for his professional help in preparing this publication.

\section{References}

BARKER, D. E., KHAN, R. A., HOOPER, R. 1994: Bioindicators of stress in winter flounder, Pleuronectes americanus, captured adjacent to a pulp and paper mill in St. George' Bay, New foundland. Can. J. Fish. Aquat. Sci. J. Can. Sci. Halieut. Aquat. 51: 2203-2209

BLAXHALL. P. C. 1972: The hematological assessment of the health of freshwater fish. J.Fish Biol. 4: 593-604

COLGROVE. G. S. 1966: Histological and hematological changes accompanying sexual maturation of sockeye salmon in the Fraser River system. Bull. Int. Pacif. Salm. Fish. Commn. 20: 1-28

DHEER, J. M. S.; DHEER, T. R.; MAHAJAN, C. L. 1987: Haematological and haematopoetic response to acid stress in an air-breathing freshwater fish. Channa punctatus Bloch. J. Fish Biol. 30: 577-588

DIXON. D. G., DICK, P. T. 1985: Changes in circulating blood cell levels of rainbow trout Salmo gairdneri Richardson, following acute and chronic exposure to copper. J. Fish Biol. 26: 475-481

DUBANSKY. V., SVOBODOVÁ, Z., VYKUSOVÁ, B. 1995: Haematological indexes of stress loading (PCB) in fish. In: Proceedings of $4^{\text {th }}$ Ichthyohaematological Conference. Hluboká n. Vltavou (Vykusová, B., Kolářová, J., Svobodová, Z. eds.), Research Institute of Fish Culture and Hydrobiology Vodňany, pp. 93-97

ELLIS, A. E. 1977: The leucocytes of fish: A review. J.Fish Biol. 11: 453-491

GILL, T. S.. EPPLE, A. 1993: Stress-related changes in the hematological profile of the American eel (Anguilla rostrata). Ecotoxicol. Environ. Saf. 25: 227-235

GILL, T. S.. PANDE, J., TEWARI. H. 1991: Effects of endosulfan and phosphamidon poisoning on the peripheral blood of fish (Barbus conchonius Hamilton). J. Environ. Sci. Health A26: 249-255

GOLOVIN, P. P., GOLOVINA, N. A. 1995: Morpho-functional characteristics of blood of Salmo trutta caspius Kessler diseased with cryptobiosis. In: Proceedings of $4^{\text {th }}$ Ichthyohaematological Conference, Hluboká $\mathrm{n}$. Vltavou (Vykusová, B., Kolářová, J., Svobodová, Z. eds.), Research Institute of Fish Culture and Hydrobiology Vodñany, pp. 117-120

GOLOVINA.N. A. 1993: Hematological indices in East- siberian sturgeon Acipenser baeri unter industrial rearing conditions. In: Proceedings of $3^{\text {rd }}$ Ichthyohaematological Conference. Litomyšl (Vykusová, B.: Svobodová. Z.; Máchová, J. eds.), Research Institute of Fish Culture and Hydrobiology Vodňany. pp. 25-26

GOLOVINA. N. A. 1995: Hematological characteristics of Trout (Oncorhynchus mykiss Walbaum) on farms of different types. In: Proceedings of $4^{\text {th }}$ Ichthyohematological Conference. Hluboká n. Vltavou (Vykusová. B.. Kolářová. J., Svobodová. Z. eds.), Research Institute of Fish Culture and Hydrobiology Vodñany, pp. 5-9 
HUMASON, G. 1979: Animal Tissue Techniques, W.H. Freeman San Francisco

HUTTON, K. E. 1967: Characteristics of the blood of adult pink salmon at three stages of maturity. Fishery Bull. Fish Wildl. Serv. 66:95-202

JENEY, Z., VALTONEN, E. T., JENEY, G.. JOKINEN, E. I. 1996: Effects of pulp and mill effluent (BKME) on physiology and biochemistry of the roach (Rutilus rutilus L.). Arch. Environ. Contam. Toxicol. 30: 523-529

JEZIORSKA, B. 1993: The effect of lethal and sublethal values of acidification on blood of carp fry. In: Proceedings of $3^{\text {rd }}$ Ichthyohaematological Conference, Litomyšl (Vykusová, B., Svobodová, Z., Máchová, J. eds.), Research Institute of Fish Culture and Hydrobiology Vodñany, pp. 34-39

KASHIW AGI. M., YOSHIDA, F., SATO. R. 1968: Blood cell constituens of chulm salmon, Onchorhynchus keta (Walbaum), with special references to the erythrocytic series according to growth of the fish from hatching. Tohocu J. Agric. Res. 19: 188-194

KHAN, R. A., BARKER. D. E., RYAN, K., MURPHY, B., HOOPER, R. G. 1996: Abnormalities in winter flounder (Pleuronectes americanus) living near a paper mill in the Humber Arm, Newfoundland. Environmental Fate and Effects of Pulp and Paper Mill Effluents (Servos. M. R., Munkittrick, K. R.;.Carey, J. H., Van der Kraak, G. J. eds.) St. Lucie Press pp.511-523

KOUŘll, J., SVOBODOVÁ, Z., VYKUSOVÁ, B., HAMÁČKOVÁ, J., PEČENÁ, M., KOCOVÁ, A. 1989: Ưčinek injekčniho podání $\gamma$-globulinu na kondični a hematologické ukazatele u generačních línů. In: Sborník 2. celostátní ichtyohematologické konference se zahraniční účastí Litomyšl (Pravda. D. ed.), CSVTS Praha, pp.256-258 (in Czech)

KUMARI, M., BANERJEE, V. 1993: Effect of lethal and sublethal levels of mercury on the blood of the fish Clarias batrachus. Environ. Ecol. 11: 465-467

NATH, R.. BANERJEE. V. 1996: Effect of pesticides methyl parathion and cypermethrin on the air-breathing fish Heteropneustes fossilis (Bloch). Environ.-Ecol. 14: 163-165

PETERS, G. 1986: Stress as a defense disturbing factor in aquaculture. International Symposium on Ichthyopathology in Aquaculture, Dubrovnik pp. 38-39

PRAVDA, D., JIRÁSEK. J., ŚRÁMEK. V., NÉMEC, D. 1985: Sezónní dynamika změn hemogramu kapřího plủdku. Sborník 1. celostátní ichtyohematologické konference Litomyšl (Pravda, D. ed.), CSVTS JmK, pp. 2533 (in Czech)

PRAVDA. D., PALÁCKOVÁ. J., LUDVÍCEK, J., STTRYMPL, M. 1993: Basic characteristics of the haemogram of Coregonus lavaretus. In: Proceedings of $3^{\text {rd }}$ Ichthyohaematological Conference, Litomyšl (Vykusová. B., Svobodová. Z., Máchová, J. eds.), Research Institute of Fish Culture and Hydrobiology Vodñany, pp. 88-96

PUlSFORD. A. L., LEMAIRE-GONY, S., TOMLINSON, M., COLLINGWOOD, N., GLYNN, P.J. 1994: Effects of acute stress on the immune system of the dab. Limanda limanda. Comp. Biochem. Physiol. 109C: 129-139

RADZINSKAYA. L. I. 1966: Changes in the blood indices of juvenile and spawning Neva salmon (Salmo salar L.). Vop. Ichtyol. 6: 568-572

ROUGIER, F., TROUTAUD, D., NDOYE, A., DESCHAUX. P. 1994: Non-specific immune response of zebrafish. Brachydanio rerio (Hamilton-Buchanan) following copper and zinc exposure. Fish Shellfish Immunol. 4: 115-127

ROWLEY. A. F.. HUNT, T. C., PAGE, M., MAINWARING, G. 1988: Fish. In Vertebrate Blood Cells (Rowley A. F.; Ratcliffe N. A., eds.) Cambridge University Press, Cambridge, pp. 19-127

REHULKA, J. 1996: Blood parameters in common carp with spontaneous spring viremia (SVC). Aquaculture International 4: 175-182

SCHWAIGER. J.. FENT. K., STECHER, H., FERLING, H., NEGELE, R. D. 1996: Effects of sublethal concentrations of triphenyltinacetate on rainbow trout (Oncorhynchus mykiss). Arch. Environ. Contam. Toxicol. 30: $327-334$

SLOMINSKA, I., WITESKA, M., JEZIERSKA, B. 1995: The effect of long-term exposure on common carp blood. $I n$ : Proceedings of $4^{\text {th }}$ Ichthyohaematological Conference. Hluboká n. Vltavou (Vykusová. B., Kolárová, J., Svobodová. Z. eds.). Research Institute of Fish Culture and Hydrobiology Vodñany. pp. 57-59

SMITH. C. E. 1968: Hematological changes in coho salmon fed a folic acid deficient diet. J. Fish. Res. Bd. Can. 25: $151-156$

SVOBODOVÁ. Z.. GROCH, L., FLAJŠHANS, M., VYKUSOVÁ. B., MÁCHOVÁ. J. 1997: The effect of longterm therapeutic bath of malachite green on common carp (Cyprinus carpio L.). Acta vet. Brno 66: $111-117$

SVOBODOVÁ. Z.. PRAVDA. D.. PALÁČKOVÁ, J. 1991: Unified methods of haematological examination of fish.. Research Institute of Fish Culture and Hydrobiology. Vodňany, $31 \mathrm{pp}$.

SVOBODOVÁ. Z.. VALENTOVÁ. V., VYKUSOVÁ. B.. PEČENÁ, M. 1987: Ichtyotoxicological evaluation of the new Czechoslovak anaesthetic for fish. Buletin VÚRH Vodñany 1: 3-7

SVOBODOVÁ,Z., PEĆENÁ M. 1988: Changes in the red and white blood picture of carp after acute exposure to toxic substances. Práce VURH Vodňany 17: 116-128

SVOBODOVÁ. Z.. KOLÁROVÁ. J.. MODRÁ. H., VAJCOVÁ. V.. HAMÁĆKOVÁ, J., KOĹ̉IL. J.. KOZÁK, P. 1998: Values of haematological indices of wels (Silurus glanis L.) in relationship to the level of nutrition during the pre-spawning period. Acta Vet. Brno 67: 235-242

SVOBODOVÁ, Z., VYKUSOVÁ. B., MÁCHOVÁ. J. 1993a: Changes in condition and haematological 
parameters in carp after long-term effect of $\mathrm{K}_{2} \mathrm{Cr}_{2} \mathrm{O}_{7} \cdot \mathrm{ZnSO}_{4} \cdot 7 \mathrm{H}_{2} \mathrm{O}$ and paranitrophenol. In: Proceedings of $3^{\text {rd }}$ Ichthyohaematological Conference, Litomyšl ( Výkusová, B.. Svōbodová, Z., Máchová, J. eds.), Institute of Fish Culture and Hydrobiology Vodňany, pp. 144-154

SVOBODOVÁ. Z., VYKUSOVÁ. B., MÁCHOVÁ, J., PEĆENÁ, M. 1993b: Changes in haematological parameters in carp after acute intoxication with $\mathrm{K}_{2} \mathrm{Cr}_{2} \mathrm{O}_{7}, \mathrm{ZnSO}_{4} .7 \mathrm{H}_{2} \mathrm{O}$ and paranitrophenol. In: Proceedings of $3^{\text {rd }}$ Ichthyohaematological Conference, Litomyšl (Vykusová, B.. Svōbodová, Z., Máchová, J. eds.), Institute of Fish Culture and Hydrobiology Vodñany, pp. 135-143

THAKUR. G. K.. PANDEY.P. K. 1990: BHC (gammaxene) poisoning effect on leucocytes of an airbreathing fish, Clarias batrachus (Linn). J. Environ. Biol. 11: 105-110

THAKUR, N., SAHAI, S. 1993: Differential leucocyte counts of some fishes during malathion intoxication. Environ. Ecol. 11: 875-878

THOMAS, A. E., ELLIOTT, J. W.. BANKS, J. L. 1969: Hematological and chemical characteristics associated with precocious male chinook salmon fingerlings. Trans. Am. Fish. Soc. 98: 23-26

TROMBICKIJ, I. D., GORBUNENKO, P. N. 1993: The influence of water pollution on the hematological parameters of bleak from the Dniester river, Moldavia. In: Proceedings of $3^{\text {rd }}$ Ichthyohaematological Conference. Litomyšl (Vykusová, B., Svobodová. Z., Máchová. J. eds.), Research Institute of Fish Culture and Hydrobiology Vodňany. pp. 161-163

VOSTRADOVSKÝ, J., SVOBODOVÁ. Z. 1983: Some adverse factors affecting Czechoslovak fisheries. Práce VÚRH Vodňany 12: 69-74

VOSYLIENE, M. Z. 1996: Haematological parameters of rainbow trout (Oncorhynchus mykiss) during short-term exposure to copper. Ekologija-Ehkologiya-Ecology 3: 12-18

WITESKA, M., JEZIERSKA, B., SLOMINSKA, I. 1995: The effect of acute lead exposure on carp blood in recovery time. In: Proceedings of $4^{\text {th }}$ Ichthyohaematological Conference, Hluboká n. Vltavou (Vykusová, B., Kolářová, J., Svobodová, Z. eds.), Research Institute of Fish Culture and Hydrobiology Vodňany, pp. 60-62

WLASOW, T. 1985: The leucocyte system in rainbow trout, Salmo gairdneri Rich., affected by prolonged subacute phenol intoxication. Acta Ichthyol. Piscator. 15: 83-94

WLASOW. T., DABROWSKA, H. 1990: Hematology of carp in acute intoxication with ammonia. Pol. Arch. Hydrobiol. 37: 419-428

WLASOW, T., DABROWSKA, H., ZIOMEK, E. 1990: Hematology of carp in prolonged sublethal ammonia intoxication. Pol. Arch. Hydrobiol. 37: 429-438

YOKOYAMA, H. O. 1960: Studies on the origin, development, and seasonal variations in the blood cells of the perch, Perca flavescens. Wildl. Dis. 6: 1-103 